\title{
Investment Decisions as a Part of Financial Literacy in the Globalized World
}

\author{
Markéta Beranová1, ${ }^{1,}$,Jan Š́ma ${ }^{2}$, and Miroslava Navrátilová ${ }^{1}$ \\ ${ }^{1}$ Czech University of Life Sciences in Prague, Faculty of Economics and Management, Department \\ of Economics, Kamýcká 129, Prague, 165 21, Czech Republic \\ ${ }^{2}$ Charles University, Faculty of Physical Education and Sport, Department of Sport and Management, \\ José Martího 269/31, Prague, 162 52, Czech Republic
}

\begin{abstract}
.
Research background: The role of knowledge and information in today's globalized world is growing. Individual approach and investment preferences play a significant role on a global scale, especially for young adults, who can make full use of investment tools.

Purpose of the article: The aim of this paper is to assess the attitude to investment amongst young university students with a focus on risk, availability, and profitability.

Methods: Primary data were obtained by quantitative research using a questionnaire survey $(n=1437)$ in 2018 amongst full time bachelor's and master's degree students at three selected universities. The universities focus on economy and agriculture and each of them is based in a different region of the Czech Republic. In the analytical part of the article, testing of statistical hypotheses was applied.

Findings \& Value added: The results show that, in terms of risk, $79.19 \%$ of respondents prefer the least risky approach. Subsequently, the question whether an investment is available when needed also plays an important role and it is preferred by $70.70 \%$ of respondents. Profitability of an investment plays the least important role and it is important for $66.59 \%$ of respondents. Statistical evaluation proved a dependence between the gender of respondents and the responses mentioned above (women prefer less risky investments as well as those immediately available to them; on the other hand, men prefer more profitable investments than women).
\end{abstract}

Keywords: investment; profitability; risk; student; university

JEL Classification: $E 22 ; F 65$; $G 11$

\footnotetext{
*Corresponding author: mberanova@pef.czu.cz
} 


\section{Introduction}

Financial literacy is investigated from many different perspectives. Research is performed by both governmental and private institutions, and also by individuals, on the level of various population segments, from individuals to international comparisons. Generally, financial literacy encompasses a mix of knowledge, skills, and attitudes necessary to achieve financial prosperity by means of prudent decision-making [1]. OECD [2] defines financial literacy as "The combination of awareness, knowledge, skills, attitude and behaviour necessary to make sound financial decisions and ultimately achieve individual financial well-being”.

The challenges of financial decision-making now faced by the younger generation are far more difficult to cope with than those faced by the previous generations. Thanks to globalization and digital technologies, financial services and products, for example, have become more complex on the one hand, but more accessible on the other. Individuals must take more responsibility for their financial decisions [3, 4].

The budget literacy part of financial literacy includes an area focusing on attitudes and approach to investments and savings. To investigate risk perception, availability, and profitability of an investment in young people who come of age and, therefore, can use financial tools with no limitations is extremely relevant. This is also confirmed by Aren and Nur Zengin [5] who add that the domain of individual preferences in investment behaviours has recently become a more and more frequent topic of research [6]. At the same time, they advance the point that the level of financial literacy and the perception of risks are mutually affected by each other. Also, Garling et al. [7] suggest that the perception of risk, as it results from the use of financial tools undoubtedly including investments and savings, is an important part of financial decision-making.

The aim of this work is based on primary research conducted at selected universities in the Czech Republic to assess the level of financial literacy of full-time bachelor's and master's degree students in relation to investment and savings. The theoretical framework is presented in the Introduction. The Methods and Materials chapter deals with the method of performing the primary research and the description of the surveyed sample of respondents in terms of basic sociodemographic characteristics. The Results and Discussion chapter presents the results of the survey and includes a discussion and a comparison of the outcomes of this research with similar surveys in terms of the investigated issues. The most important findings are shown in the Conclusion chapter.

\section{Methods}

The theoretical framework of this article has been elaborated through the method of document research using scientific articles. Primary data were collected using a questionnaire survey which was conducted in 2018. The respondents were full-time students at three selected universities in the Czech Republic focused, among other things, on agriculture, forestry, and veterinary science.

These were the University of South Bohemia in České Budějovice (hereinafter referred to as USB), the Mendel University in Brno (hereinafter referred to as MEU), and the Czech University of Life Sciences in Prague (hereinafter referred to as CZU). At each university, the researchers approached both respondents studying at the faculties focused on economics (at USB this was the Faculty of Economics, at MEU it was the Faculty of Business and Economics, and at CZU it was the Faculty of Economics and Management) and respondents studying at faculties not specializing in economics (at USB this was the Faculty of Agriculture, at MEU it was the Faculty of Agri Sciences, and at CZU it was the Faculty of Environmental Sciences). In total, $1,437(\mathrm{n}=1,437)$ respondents took part in the primary 
research. The sample was determined based on quota sampling and represented $14 \%$ of the total number of students at the selected faculties.

Basic sociodemographic factors of the reference group of respondents were as follows (at the same time, each of these characteristics stands for one investigated variable):

Table 1. Sociodemographic factors of respondents in \%.

\begin{tabular}{|c|c|c|}
\hline \multirow{2}{*}{ Gender } & Female & 57.48 \\
\cline { 2 - 3 } & Male & 42.52 \\
\hline \multirow{2}{*}{ Level of study } & Bachelor's degree (BD) & 66.32 \\
\cline { 2 - 3 } & Master's degree (MD) & 33.68 \\
\hline \multirow{2}{*}{ Field of Study } & Economic studies (ECO) & 63.40 \\
\cline { 2 - 3 } & Non-economic studies (NON-ECO) & 33.60 \\
\hline \multirow{2}{*}{ University } & CZU & 59.29 \\
\cline { 2 - 3 } & USB & 18.02 \\
\cline { 2 - 3 } & MEU & 22.69 \\
\hline
\end{tabular}

\subsection{Statistical Tools for Analysis}

The contingency table is used for transparent visualization of mutual relations of two statistical variables. The type of the contingency table is given by the number of rows $r$ and the number of columns $\mathrm{s}$, it means $\mathrm{r} \times \mathrm{s}$ [8]. Obviously, $\chi^{2}$ is a measure of the overall dissimilarity of $n_{i j}$ and $m_{i j}$. The greater the difference between the observed and the expected values, the higher the test statistic $\chi^{2}$.

$$
\begin{gathered}
m_{i j}=\frac{n_{i} \cdot n_{j}}{n} \\
\chi^{2}=\sum_{i=1}^{r} \sum_{j=1}^{s}\left(n_{i j}-m_{i j}\right)^{2} / m_{i j}
\end{gathered}
$$

$\mathrm{i}$ and $\mathrm{j}$ are indices of rows and columns, nij are observed frequencies, ni and $\mathrm{nj}$ are marginal totals, $\mathrm{n}$ is grand total of observations, mij are expected frequencies. $\chi^{2}$ is compared to the critical value $\chi^{2}$ with a chi-square distribution of $(\mathrm{r}-1)(\mathrm{s}-1)$ degrees of freedom at the chosen level of significance $(\alpha=5 \%)$. The hypothesis is rejected if $\chi^{2}$ is larger than the table value. This test is valid asymptotically and, thus, can only be applied if there are enough observations. All expected values ought to be higher than one [9]; at the same time, the table should not contain more than $20 \%$ of theoretical incidence rates (frequencies) of less than 5 . Where zero values occur in any of the fields, analysis of a derived table created by merging a small number of categories [9] was performed. Cramer's V was used to determine the degree of association between the variables.

The data analysis was focused on the following tested hypotheses.

- The authors, in the form: surname followed by the initials of the first names (only the first letter capitalized with full stops after the initials),

- $\mathrm{H}_{1}$ : Preference given to the least risky saving or investment scheme is independent of gender.

- $\mathrm{HO}_{2}$ : Preference given to the least risky saving or investment scheme is independent of the university.

- $\mathrm{HO}_{3}$ : Preference given to the least risky saving or investment scheme is independent of the specialization of the faculty.

- $\mathrm{HO}_{4}$ : Preference given to the availability of the invested money is independent of gender.

- $\mathrm{H}_{5}$ : Preference given to the availability of the invested money is independent of the university. 
- $\mathrm{H}_{6}$ : Preference given to the availability of the invested money is independent of the specialization of the faculty.

- $\mathrm{H}_{7}$ : Preference given to the highest potential profitability of investment or savings is independent of gender.

- $\mathrm{H}_{8}$ : Preference given to the highest potential profitability of investment or savings is independent of the university.

- $\mathrm{H}_{9}$ : Preference given to the highest potential profitability of investment or savings is independent of the specialization of the faculty.

\section{Results and Discussions}

Respondents in the survey are university students who can utilize investment and saving instruments in full and, therefore, this issue is of utmost relevance. Respondents were asked to answer questions about what is most important to them when they invest or choose a saving scheme (also theoretically) - the questions comprised profitability of investment, risk, and liquidity.

The results below show (Table 2) that the dependence between the preference given to the least risky investments or savings and the respondent's gender, university, and specialization of the faculty has been proved. It is shown here that the respondents answered "Rather yes" most often $-50.66 \%$ (728). The unambiguous answer "Yes" was chosen by $28.53 \%$ (410) of respondents. The answer "Rather not" was represented by $11.97 \%$ (172) of respondents. The clear answer "No" was given by 3.83\% (55) of participants and $5.01 \%(72)$ of participants answered "I do not know". It can be concluded from the results that the respondents are very careful in their approach to investments and savings in terms of the degree of risk.

Table 2. Preference given to the least risky investment in relation to the variables.

\begin{tabular}{|c|c|c|c|c|c|}
\hline $\begin{array}{c}\text { Hypothesis } \\
\text { No. }\end{array}$ & $\begin{array}{c}\text { Wording of the zero } \\
\text { hypothesis }\end{array}$ & $\chi^{2}$ & $\begin{array}{c}\text { Critical } \\
\text { value }\end{array}$ & $\begin{array}{c}\text { Ho can be } \\
\text { rejected }\end{array}$ & $\begin{array}{c}\text { Cramer's } \\
\text { V }\end{array}$ \\
\hline $\mathrm{H} 0_{1}$ & $\begin{array}{c}\text { Preference given to the least } \\
\text { risky saving or investment } \\
\text { scheme is independent of } \\
\text { gender. }\end{array}$ & 46.47 & 9.49 & $\mathrm{X}$ & 0.18 \\
\hline $\mathrm{H}_{2}$ & $\begin{array}{c}\text { Preference given to the least } \\
\text { risky saving or investment } \\
\text { scheme is independent of the } \\
\text { university. }\end{array}$ & 31.73 & 15.51 & $\mathrm{X}$ & 0.11 \\
\hline $\mathrm{H} 0_{3}$ & $\begin{array}{c}\text { Preference given to the least } \\
\text { risky saving or investment } \\
\text { scheme is independent of the } \\
\text { specialization of the faculty. }\end{array}$ & 33.87 & 9.49 & $\mathrm{X}$ & 0.15 \\
\hline
\end{tabular}

When investigating the influence of gender, the calculated value of statistics $\chi 2(46.47)$ is substantially higher than the critical value at the level of significance of 0.05 (9.49). The zero hypothesis can be rejected. The dependency between the preference given by respondents to investment or saving schemes with the least risk and their gender has been proved. The value of Cramer's $\mathrm{V}$ is at the 0.18 level which means that the dependency is weak. A statistically significant difference at the 0.001 level was identified for the "Rather not" answer, which was given by men $(17.51 \%, 107)$ more often than by women $(7.87 \%$, $65)$, and at the 0.01 level for the "No" answer, which was also given by men $(5.73 \%, 35)$ more often than by women $(2.42 \%, 20)$. A statistically significant difference at the 0.05 level was observed in the "Yes" answer - this answer was given by women $(30.99 \%, 256)$ more 
often. It follows that when choosing an investment or saving scheme, women are more risk aware than men who are more willing to take a higher risk. After comparing the value of statistics $\chi 2$, which is higher than the critical value at the level of significance of 0.05 , the zero hypothesis can be rejected. The dependency between the preference given by respondents to investment or saving schemes with the least risk and the university attended by the respondent has been proved. The value of Cramer's V is at the 0.11 level and, thus, exhibits a very weak dependency. Further investigation performed with the help of adjusted residuals showed a statistically significant difference (the level of significance at 0.001) between theoretical and empirical frequencies of the "Rather yes" answer given by the students of USB $(41.31 \%, 107)$ who chose this answer significantly less often. At the 0.01 level, a difference between the frequency of "Yes" $(36.68 \%, 95)$ and "No" $(6.18 \%, 16)$ answers given by the respondents from SBU was observed. It follows that when deciding about the selection of an investment or saving scheme with the least risk, students from SBU tend to choose the "Yes" answer as compared with the "Rather yes" answer which means that the risk level of an investment or saving scheme plays an important role for them. When investigating the influence of the specialization of the faculties attended by the respondents, the value of statistics $\chi^{2}$ (33.87) was found to be significantly higher than the critical value at the level of significance of 0.05 (9.49). The zero hypothesis can be rejected. The dependency between the preference given by respondents to investment or saving schemes with the least risk and the specialization of the faculty attended by the respondent has been proved. The value of Cramer's $\mathrm{V}$ is at the 0.15 level and, thus, exhibits a weak dependency. The dependencies between specific characteristics were identified with the help of adjusted residuals. At the 0.001 level, a statistically significant difference was found between the "Yes" answer, which was chosen significantly more often by students of non-economics faculties $(35.17 \%, 185)$, and the "Rather not" answer, which was chosen by economics faculties more often $(14.16 \%, 129)$. It follows that students of non-economics faculties are very cautious when it comes to the risk level of an investment or saving scheme and the risk level plays an important role for them.

Another question on attitudes to investments and savings asked the respondents if it is important for them to have the invested money immediately available. The most frequent answer to this question was "Rather yes" which was given by $45.37 \%$ (652) of respondents. $25.33 \%$ (364) of respondents answered "Yes", 21.50\% (309) of respondents chose the "Rather not" option, and as few as $4.45 \%$ (64) of them answered "No". Only a minimum of respondents, 3.34\% (48), answered "I do not know".

Table 3. Preference given to the liquidity of investment in relation to the variables.

\begin{tabular}{|c|c|c|c|c|c|}
\hline $\begin{array}{c}\text { Hypothesis } \\
\text { No. }\end{array}$ & Wording of the zero hypothesis & $\chi^{2}$ & $\begin{array}{c}\text { Critical } \\
\text { value }\end{array}$ & $\begin{array}{c}\text { Ho can be } \\
\text { rejected }\end{array}$ & $\begin{array}{c}\text { Cramer's } \\
\text { V }\end{array}$ \\
\hline $\mathrm{H}_{4}$ & $\begin{array}{c}\text { Preference given to the availability } \\
\text { of the invested money is } \\
\text { independent of gender. }\end{array}$ & 33.22 & 9.49 & $\mathrm{X}$ & 0.15 \\
\hline $\mathrm{H} 0_{5}$ & $\begin{array}{c}\text { Preference given to the availability } \\
\text { of the invested money is } \\
\text { independent of the university. }\end{array}$ & 9.10 & 15.51 & - & - \\
\hline $\mathrm{H}_{6}$ & $\begin{array}{c}\text { Preference given to the availability } \\
\text { of the invested money is } \\
\text { independent of the specialization of } \\
\text { the faculty. }\end{array}$ & 16.96 & 9.49 & $\mathrm{X}$ & 0.11 \\
\hline
\end{tabular}

When investigating the influence of gender, the value of statistics $\chi 2$ is substantially higher (33.22) than the critical value at the level of significance of 0.05 (9.49). The zero hypothesis can be rejected. The dependency between the preference given by respondents to availability of the invested money and their gender has been proved. The value of Cramer's 
$\mathrm{V}$ is at the 0.16 level which means that the dependency is weak. The dependencies between specific characteristics were identified with the help of adjusted residuals. A statistically significant difference at the 0.001 level was identified for the "Rather not" answer, which was given by men $(27.33 \%, 167)$ significantly more often than by women $(17.19 \%, 142)$. At the 0.01 level, a difference was identified for the "Yes" answer, which was given by women $(28.57 \%, 236)$ more often than by men $(20.95 \%, 128)$. This result clearly implies that to have the invested money available is more important for women than for men. After comparing the value of statistics $\chi^{2}$, which is higher than the critical value at the level of significance of 0.05 , the zero hypothesis can be rejected. The dependency between the preference given by respondents to availability of the invested money and the specialization of the faculty attended by the respondent has been proved. The value of Cramer's V is at the 0.11 level and shows a weak dependency. More detailed investigation performed with the help of adjusted residuals showed a statistically significant difference at the 0.01 level of significance between theoretical and empirical frequencies of the "Yes" answer given by the students of noneconomics faculties $(30.04 \%, 158)$ who chose this answer more often. It follows from the above that students of non-economics faculties give preference to saving or investments schemes where the deposited money is immediately available to them.

The last question asked about investments and savings was the question asking respondents whether they prefer saving or investment schemes with the highest possible return. In their responses to this question, 26.58\% (382) of the total number of respondents answered "Yes" while 40.01\% (575) chose the "Rather yes" option. The "Rather not" option was chosen by $23.17 \%$ (333) of respondents and only 4.73 (68) of respondents stated "No". $5.50 \%$ (79) of participants answered by choosing "I do not know".

Table 4. Preference given to the profitability of investment in relation to the variables.

\begin{tabular}{|c|c|c|c|c|c|}
\hline $\begin{array}{c}\text { Hypothesis } \\
\text { No. }\end{array}$ & Wording of the zero hypothesis & $\chi^{2}$ & $\begin{array}{c}\text { Critical } \\
\text { value }\end{array}$ & $\begin{array}{c}\text { Ho can } \\
\text { be } \\
\text { rejected }\end{array}$ & $\begin{array}{c}\text { Cramer's } \\
\text { V }\end{array}$ \\
\hline $\mathrm{H}_{7}$ & $\begin{array}{c}\text { Preference given to the highest } \\
\text { potential profitability of investment } \\
\text { or savings is independent of gender. }\end{array}$ & 20.84 & 9.49 & $\mathrm{X}$ & 0.12 \\
\hline $\mathrm{H} 08$ & $\begin{array}{c}\text { Preference given to the highest } \\
\text { potential profitability of investment } \\
\text { or savings is independent of the } \\
\text { university. }\end{array}$ & 27.94 & 15.51 & $\mathrm{X}$ & 0.10 \\
\hline $\mathrm{H} 09$ & $\begin{array}{c}\text { Preference given to the highest } \\
\text { potential profitability of investment } \\
\text { or savings is independent of the } \\
\text { specialization of the faculty. }\end{array}$ & 7.53 & 9.49 & - & - \\
\hline
\end{tabular}

The value of statistics $\chi 2$ is higher than the critical value at the level of significance of 0.05 . The zero hypothesis can be rejected. Thus, the dependency between the preference given by respondents to the highest possible return on the investment and their gender has been proved. The value of Cramer's V is at the 0.12 level and shows a weak dependency. The dependencies between specific characteristics were identified with the help of adjusted residuals. A statistically significant difference at the 0.01 level was identified for the "I do not know" answer, which was given by women $(7.16 \%, 59)$ significantly more often than by men $(3.26 \%, 20)$. At the 0.05 level, a difference was identified for the "Yes" answer, which was given by men $(29.79 \%, 182)$ more often than by women $(24.21 \%, 200)$ and, also, for the "Rather not" answer, which was given by women $(25.54 \%, 211)$ more often than by men $(19.97 \%, 122)$. This result implies that profitability of their investment plays a less important role for women than for men. 
The calculated value of statistics $\chi^{2} 6.84$ is higher than the critical value on the level of significance of 0.05 . Thus, the zero hypothesis can be rejected. The dependency determined by Cramer's $V$ only reached the value of 0.10 , which means that it is weak. The differences between the calculated and actually measured occurrences imply a statistically significant difference at the 0.001 level in the "Rather not" answer given by the USB students who chose this option quite often $(31.66 \%, 82)$, and also at the 0.05 level in the "No" answer given by the SBU students $(6.95 \%, 18)$. It follows that the preferred highest potential profitability of their investment or saving scheme is the least important for the USB students as compared to students of the other universities.

Financial literacy at universities and the assessment of financial literacy directly in this segment seems not to have been a widespread topic up to now $[10,11]$. Over the several recent decades, experts and teachers have expressed their concerns about whether young people, after graduating from university, possess adequate knowledge to meet the needs of building and managing a healthy financial life and making the right decisions [12]. Therefore, research in this domain has become more and more relevant all over the world.

The results of the survey show that all three areas of decision-making regarding preferences in investing and saving depend on the gender of respondents. In terms of risks associated to investments and savings, women are more careful than men, who are more willing to take a risk. The same applies to women's preference to availability of the invested money; men prefer profitability more than women. Gender differences in investment risktaking are dealt with in many studies [13-15]. Our results are in harmony with the conclusions by Bannier and Neubert who point out that the tolerance towards investment risk prevails among men [13].

The influence of both the university and specialization of the faculty was proved in two investigated hypotheses. The preference to the least risky investment or saving scheme was proved for the university (only a weak dependence) and the specialization of the faculty. In terms of the specialization, low-risk investment and saving schemes were preferred by students of non-economics studies. Also, students of non-economics faculties prefer saving or investment schemes where the deposited or invested money is available to them. This observation is in harmony with Kubak et al., [16] who in their research conclude that studying subjects related to economics enhances financial literacy and knowledge and that it can also have an impact on decision-making as well as the execution of informed decisions. In this respect, the opinion held by Fernandes, Lynch and Netemeyer [17] differs as they say that knowledge acquired through study is only temporary.

\section{Conclusion}

The research investigated financial literacy of university students in the Czech Republic. The results were obtained through a questionnaire survey which was conducted at three selected universities in 2018. The focus was on the area of decision-making and preferences in relation to investments and savings. It can be concluded that the potential degree of risk involved in an investment or saving scheme is very important for the respondents during the decisionmaking process, and dependencies were observed in all three variables. Availability of the invested money and profitability of the investment or saving scheme were each observed in two variables. The research was performed at the selected universities in the Czech Republic only, which may be considered as a limitation. Further research can focus on high schools to assess the development of financial literacy towards universities.

This work was also supported by the Internal Grant Agency of Faculty of Economics and Management, Czech University of Life Sciences Prague - grant number 2020B0002 - "The impact of climate change on the economic performance of the viticulture and wine-making sector in the Czech Republic". 


\section{References}

1. MF ČR (2017). Ministerstvo financí $\check{C} R$ : Proč se finanční vzdělávat? - Definice pojmu. Retrieved from : https:/www.psfv.cz/cs/pro-odborniky/strategicke-dokumenty

2. OECD (2018). OECD/INFE Core competencies framework on financial literacy for MSMEs. Retrieved from: https://www.oecd.org/finance/financial-education/OECDINFE-core-competencies-framework-on-financial-literacy-for-MSMEs.pdf

3. Beranová, M., Navrátilová, M., Šišková, J., Stárová, M. (2017). Financial literacy of university students in relation to financial security in old age. In M. Houska et al. (Eds.), Proceedings of the 14th International Conference Efficiency and Responsibility in Education (ERIE) (pp. 25-32). Prague: Czech University of Life Sciences Prague.

4. Gavurová, B., Huculova, E., Kubák, M., Cepel, M. (2017). The state of students' financial literacy in selected slovak universities and its relationship with active pension savings. Economics and Sociology, 10, 206-219.

5. Aren, S., Zengin, A. N. (2016). Influence of Financial Literacy and Risk Perception on Choice of Investment. Procedia - Social and Behavioral Sciences, 235, 656-663.

6. Dinc Aydemir, S., Aren, S. (2017). Do the effects of individual factors on financial risktaking behavior diversify with financial literacy? Kybernetes, 46(10), 1706-1734.

7. Gärling, T., Kirchler, E., Lewis, A., Van Raaij, F. (2009). Psychology, Financial Decision Making, and Financial Crises. Psychological Science in the Public Interest, 10(1), 1-47.

8. Hindls, R., Hronová, S., Seger, J., Fischer, J. (2007). Statistika pro ekonomy. Praha: Professional publishing.

9. Hendl, J. (2009). Přehled statistických metod: analýza a metaanalýza dat. Praha: Portál.

10. Gerrans, P., Heaney, R. (2019). The impact of undergraduate personal finance education on individual financial literacy, attitudes and intentions. Accounting \& Finance, 59(1), 177-217.

11. Philippas, N. D., Avdoulas, C. (2019). Financial literacy and financial well-being among generation-Z university students: Evidence from Greece. The European Journal of Finance, 22(1), 360-381.

12. Bramhandkar, A., Clair, St. U., Shields, B. A. (2019). Financial literacy of graduating seniors at a small private College. The Business and Management Review, 10(2), $265-$ 273.

13. Bannier, Ch. E., Neubert, M. (2016). Gender differences in financial risk taking: The role of financial literacy and risk tolerance. Economics Letters, 145, 130-135.

14. Ertac, S., Gurdal, M. Y. (2012). Deciding to decide: Gender, leadership and risk-taking in groups. Journal of Economic Behavior \& Organization, 83(1), 24-30.

15. Halko, M.-L., Kaustia, M., Alanko, E. (2012). The gender effect in risky asset holdings. Journal of Economic Behavior \& Organization, 83(1), 66-81.

16. Kubák, M., Tkáčová, A., Androniceanu, A., Tvaronavičienė, M. and Huculová, E. (2018). Financial literacy of students in chosen universities - research platform for regulatory processes of educational system in Slovakia. E+M Ekonomie a Management, 21(1), 175-190.

17. Fernandes, D., Lynch, J. G. and Netemeyer, R. G. (2014). Financial Literacy, Financial Education, and Downstream Financial Behaviors. Management Science, 60(8), 18611883. 